\title{
Assessing Destination Branding and Hotel Performance of the South East Asia Market
}

\author{
Mohd Raziff Jamaluddin ${ }^{1}$, Agus Riyadi ${ }^{2}$ \\ ${ }^{1}$ Universiti Teknologi MARA, Cawangan Selangor, Malaysia \\ ${ }^{2}$ Sekolah Tinggi Pariwisata Trisakti, Jakarta, Indonesia \\ Email: ${ }^{1}$ raziff@ salam.uitm.edu.my and ${ }^{2}$ agus.riyadi@ stptrisakti.ac.id
}

\begin{abstract}
South East Asia (SEA) has progressed well in the past ten years in attracting tourist arrivals.However no specific reason can explain the performance of the destination especially in this region. This studyattempted to assess the role of destination branding with the tourist arrivals and hotel performance of the selected SEA countries. The different context of branding as in destination and hotel made it impossible to conduct a study about branding however there are similarities in branding effort that these two discipline can synchronize. This study utilized the statistic that made available online and utilized the data by presenting in the table form for easy understanding. This research found that general destination branding has no impact to the tourist arrivals and hotel occupancy rate. Future study should examine the impact of destination branding to niche hotel segment using international respondents that have visited all SEA countries.
\end{abstract}

Keywords—Destination, Hospitality, Tourism, Branding, and Performance.

\section{INTRODUCTION}

Tourism in South East Asia (SEA) has evolved tremendously in line with the progress of the member countries after gaining independence from their colonial master. Unlike Western countries, South East Asia countries can be considered in the early stage of the tourism development where majority of the countries had just started the tourism efforts in 1960's with the development of airports, hotels, immigration bureau, and banking system. However, tourism has quickly become one of the major revenue generators for SEA countries especially when industrial and banking segment recorded volatile performance in every ten years.

The development of tourism and hotel industry after the post-independence era occurred based on the progress of the aviation industry and industrial revolution. During this time agricultural was the main industry in SEA until the revolution of manufacturing industry in 1980s. The number of luxury hotels during this time was limited where majority of them were built in the city center to attract either business travelers or convention delegates. The number of holiday travelers were limited during $1960 \mathrm{~s}-1980$ s because tourism and hospitality industry were not considered as the core industry that generate income for the nation.

Tourism industry has shown a resilient performance in the post-modernism era where it has started to be recognized as the top three revenue generators. According to (UNWTO, 2017), international tourist arrivals have increased significantly over the past decades. The statistic showed that the number had increased from 25 million in 1950 to 278 million in 1980, to 674 million in 2000, and 1,235 million in 2016. The increase in tourist arrivals were positively associated with the increase in tourism receipts where the value had increased from US\$2 billion in 1950 to US\$ 104 billion in 1980, US $\$ 495$ billion in 2000, and US\$1,220 billion in 2016.

From the statistic above, the increase in tourist arrivals rose significantly by more than 1000 per cent (1960s to 1980s) while recorded approximately 50 percent (2000 to 2016). Looking at this trend, it shows that there are opportunities for the sub-industry under hospitality segment to seize the chances of offering products to the international tourist arrivals. Hotel industry for instance, is the complement products in the travel packages. Travelers allocated 40 percent of the travel budget for accommodation expenses thus making the decision to stay is among the priority during the planning process. 
The importance of tourism industry has prompted the countries to invest huge amount of money to improving infrastructure and also came out with the strategic marketing. The concept of tourist destination has taken place since1980s where destination is comprised of products, services and experiences with various participants involved in realizing them. Later it has become a source of core competency which is used by the tourism agency for differentiation purposes. Among popular topic in destination studies are destination competitiveness and destination branding. There are several emerging topics that appeared as a spin-off of general topic like sustainable destination, sports destination, medical destination and many more.

Looking back at the progress of the sub-industry within hospitality and tourism sector; hotel industry recorded a rapid progress with a growing number of luxury hotel establishments since 1960's. For a record, the first luxury hotel in Asia was built in Colombo, Sri Lanka in 1864 while in Malaysia, the first hotel was built in the historical city of Malacca by the name Puri Hotel. The highly popular sea transport made a city with an international hub for transporting ship was the first criteria for hotel development. This can be evident in Penang, Malaysia where the first hotel built by the name Eastern and Oriental offered comprehensive hotel facilities that suit business segment that is close to the port (Kastrone,I., 2009). Unlike Malaysia, the first hotel establishment in Indonesia was built on the royal residence as evident in Royal Ambarrukmo at Yogyakarta in the late 1850's (Margi,R., 2015).

Another significant progress on the hotel development was happened with the advancement of technology. The first systematic utilization of full air-conditioning systems in luxury hotels in Singapore in 1960s (Rimmer,P.J., \& Dick,H.W., 2009) Singapore, the smallest city in SEA invested in technology and infrastructure to attract people to the republic. It is evident that the progress of hotel industry in Singapore happened as a result of the advancement of the service industry in particular financial, shipping and airlines.

While in Thailand, river is the key of development for its major city. After the fall of the old Ayutthaya, Bangkok has taken place as the major city for the country where majority of the hotels were developed near to the Chao Phraya River. In addition, a move of the King's palace from Ayutthaya to Bangkok marked the beginning of tourism in Bangkok since 1760s. For the Philippines, not much can be retrieved on the historical development of hotel industry, nonetheless through online search; The Manila Hotel was among the earliest hotel in Manila, built in 1909. This hotel was popular for the colonists during the World War II due to the plenty number of rooms available in this hotel (Uratex Foam, 2015).

Similar to tourism industry, hotel industry is also a segment that offer a place to stay, dine and banquet functions. The transformation of hotel from merely a generic establishment into becoming star-rated facilities and lately competing on differentiation has prompted researchers in the hotel industry to examine the role of services and branding in the hotel industry. Service quality and brand image are among the popular consumer behavioral studies in the hotel industry.

\section{LITERATURE REVIEW}

\section{A. Consolidating Issue in Tourism and Hotel Research}

Research in hospitality and tourism disciplines have undergoing a transformational process since late 1990s with studies that examined niche areas and getting cited by the new generation of scholars. The highly affected discipline is marketing where various topics were introduced and pursued by the hospitality and tourism scholars. The underlying reason for this is because of the saturation in popular topics in marketing in particular "Product Life Cycle" (Vernon,R., 1966); "SWOT Analysis" (Hill, T., \& Westbrook,R., 1997); and "Marketing Mix" (McCarthy,E.J., 1968).

In tourism and hospitality industry, the element of immobility in the form of fixed assets has resulted in limitation to adopt Product Life Cycle and SWOT Analysis. Destination and hotel for instance operating in the same geographical area for a long period of time if not endlessly. The huge initial start-up in the form of facilities and constructions made it impossible to deploy and re-deploy strategies. Hence, the cost of developing tourism and hospitality products used a strategic planning method where the decision to invest in destination and hotel usually took more than 10 years to assess the success. 
In relation to the previous paragraph, the marketing mix is also arguable for the present situation. The element of 4p's can be considered inapplicable for highly saturated industry in particular city hotel. For instance, hotel in the city center can offer exactly generic product at the same location with a comparable price. With the advancement of information communication technology, online marketing is a common strategy. However for destination management, the differences in resources and cost of development making it difficult to adopt one strategy that fits all.

With regard to the previous paragraph, a few attempts were taken for combining the macroeconomic of the tourism industry and microeconomic of hotel segment under one study to examine the correlation of both studies for destination competitiveness. This research aims to examine the factors that can contribute to better synchronization of tourism and hotel industry based on the comprehensive literature search and analyzing facts and figures. By understanding the fundamental of both industries, the policymakers and industry practitioners can establish straightforward framework that can benefit the economy of the country and also South East Asian region.

\section{B. Related Works Service Industry}

To understand tourism and hospitality industry, one must comprehend the major industries that form the world economy. Based on the literature search, scholars agreed that there are four major industries as depicted in Table I. (Amin, M., 2010) noted that service industry relies less on physical infrastructure and machines as compared to other industry that depends so much on human capital. Even with the rapid progress on information communication technology, and automation, manufacturing and construction industry involves great utilization of individual and groups in a single and multiple projects (Bertelsen,S., 2002).

\section{TABLE I. SEMANTIC DEFINITION OF MANUFACTURING, SERVICE, CONSTRUCTION} AND AGRICULTURE

\begin{tabular}{ll}
\hline \multicolumn{1}{c}{ Industry } & \multicolumn{1}{c}{ Definition } \\
\hline Manufacturing & $\begin{array}{l}\text { The process of converting raw materials, components, or parts into finished goods that } \\
\text { meet a customer's expectation. Manufacturing commonly employs a man-machine }\end{array}$ \\
setup with the division of labor in a large scale production (Businee Dictionary Online). \\
Service & $\begin{array}{l}\text { Industry made up of companies that primarily earn revenue through providing } \\
\text { intangible products and services (Businee Dictionary Online). }\end{array}$ \\
Construction & $\begin{array}{l}\text { Sector of national economy engaged in the preparation of land and construction, } \\
\text { alteration, and repair of buildings, structures, and other real property (Businee }\end{array}$ \\
Agriculture & $\begin{array}{l}\text { Dictionary Online). } \\
\text { The science or practice of farming, including cultivation of the soil for the growing of } \\
\text { crops and the rearing of animals to provide food, wool, and other products (Oxford } \\
\text { English Dictionary Online). }\end{array}$ \\
\hline
\end{tabular}

Service industry accounted for 60 to 80 percent of GDP and employment in majority of the developed countries in the late $20^{\text {th }}$ century (Howells,J., 2004). It was not until 1960s that the service industry has started to gain recognition from the developing countries where agricultural has become the core industry due to the lacking in expertise and technological advancement. According to (Amin,M., 2010), the ability of the service industry to outperform other industry is based on four significant factors specifically (a) rely less on electricity and machines but more on human capital; (b) better integrated into the financial system; (c) similar production structure and firm characteristic with manufacturing firms; and (d) larger and generate more sales per worker.

\section{Tourism Industry}

Tourism is formed between two important concepts in particular a visitor and the activity. IRTS (2008) defined a visitor as a traveler taking a journey to a destination outside his/her comfort, for less than a year for a business, leisure or personal motive other than employment or studying in the visited place. On the other hand, travel refers to the activity of the visitor in the duration of the journey with regard to geographical, duration and activity. Hence, a subset of travel and visitors are a subset of 
travelers or in simple term tourism [16]. The study of tourism usually involved the demand and supply side of the travelling and typically involved economy at large.

\section{Tourist Destination}

Buhalis,D (2015) defined tourist destination as a region that has geographical identity and comprehensive political and legislative framework that able to be utilized in the tourism marketing and planning. He further added, tourist destination is an "effort" for the stakeholders within the country to formulate quality and unique experiences for the benefit of the society and place itself. Tourist destination began as a product of the nation but over time it has undergone transformation for being merely a "national product/identity" into more competitive traits with the evolution of research in destination competitiveness and sustainable tourism.

\section{Hospitality Industry}

Powers,T \& Barrows,C (2006) note that hospitality was derived from "hospice", the term for a medieval house of rest for travellers and pilgrims. Semantic definition of hospitality in the dictionary refers hospitality as 'the friendly and generous reception and entertainment of guests, visitors, or strangers' (Oxford English Dictionary Online). Mackenzie,M., \& Chan, B (2009) meanwhile, defined hospitality as "the act of kindness in welcoming and looking after the basic needs of guests or strangers, mainly concerning food, drink, and accommodation."

\section{Hotel Industry}

In the early evolution of lodging, it is commonly divided into two categories namely hotel and motel (Chon, K.S., \& Sparrowe,R.T., 2010; Powers, T \& Barrows, C., 2006). However, Creswell, J.W., 2009) notes that the term 'Inn' was used to identify the house that offered food and shelter to the public. She added that the demand for accommodation along the roadside became the factor the house owner obligated to host the travellers and treated as part of the family. In the hospitality industry, the word "hotel" is of French origin that derived from the hostel that is used by Romans to indicate a stranger who stayed at the house of others and being entertained by the house owner (Sherry, J.E., 1993). She notes that hotel represents upper-class accommodation as this was originally practiced by the wealthier Romans that extend the hospitality of the house to their friends and respectable travellers.

\section{Tourism or Hospitality Industry}

There are lots of argument on the "which is which" for tourism and hospitality as found in the academic books, directories and research articles. From the tourism perspective, the sub-industries under hospitality industry are the major players in the supply and demand of the tourism industry (IRTS, 2008; Power, T \& Barrows, C., 2006) on the other hand suggested hospitality industry is made of four major components specifically lodging, foodservice, culinary, and travel and tourism. However (Chon, K.S., \& Sparrowe,R.T., 2010) refer both industries under one group that they name it as hospitality and tourism network.

\section{The Central of Tourism and Hospitality Research}

There are many topics brought by the scholars in the field of tourism and hospitality research where popular topics like demand and supply of the tourism products, employment, destination competitiveness and sustainability dominated the studies in the tourism discipline (IRTS, 2008). While for hospitality industry, there are wide topics being studied by the scholars that encompass the revenue and cost center, service delivery and consumer behavior.

Regardless of the topic being brought up by both disciplines, a research can only achieve one main objective by either looking at i) cost-effectiveness that will maximize profits, or ii) long-term relationship that will create sustainable market segment. In facing this dilemma, majority of the researchers keen with the first alternative because of the sense of appealing to fulfill the industry's need. However the sense of engagement between industry-academia makes this objective beyond reach. As a result, majority of the researches conducted in the service, hospitality and tourism industry examine the effectiveness, perceived usefulness, ability and quality towards popular outcome determinations like satisfaction, trust, commitment, engagement and behavioral intention. Taking 
customer/guest/tourist as the unit of analysis, the practical implication of the findings toward the industry players remain uncertain thus made the findings as having no commercial appealing.

Therefore, this research will look into finding a basic relationship between tourism and hospitality to encourage more interdisciplinary studies to be conducted in the future because both industries are complementing each other to ensure the progress of the nation.

\section{A. Research Design}

\section{III.METHODS}

For the present research, as referring to (Cresswell, J.W., 2009) "Four Worldviews," that comprised of Postpositivism, Constructivism, Participatory, and Pragmatism; this research is conducted to understand the indirect relationship between macro levels of the economy toward the performance of the micro segment of the industry. This research followed "constructivism" worldview as suggested by (Cresswell, J.W., 2009) where this research looked at multiple participant meanings namely the tourism performance and also hotel industry statistics. Furthermore, this research overviewed historical development of the tourism and hospitality industry before implying possible future theory generation.

\section{B. Data}

For the present research, an intensive literature search was conducted to suggest the significant bottom-line based on the comparison and contrast of both disciplines. The literature was gathered from the online sources based on the subscription of the database by the universities of the respective authors. Prominent statistics supplier like United World Tourism Organization (UNWTO), International Recommendation for Tourism Statistics (IRTS) and Smith Travel Research (STR) were utilize for comprehending the current states of tourism and hospitality industry. Furthermore, published article that highlighted the progress of tourism and hospitality industry were carefully analyzed before suggesting the findings.

\section{Method}

This research is argumentative essay in nature. The findings were presented based on the special theme found during the literature search. This research deployed a systematic review of the articles in the area that the researcher found the most prominent as highlighted by scholars in the area of tourism and hospitality. The review of the articles was based on the published articles that covered the progress of both industries since 1960s. The systematic review is selected because of lack of documented studies that compare between tourism and hospitality previously. Furthermore, this research attempted to identify and highlight the relevant research by gathering, reporting and assessing the findings. The aim of the systematic reviews deployed in this research was to find the correlation between findings and outputs of the previous research.

\section{Scope of the Study}

The research examined key driver of competitions for several destinations and also analyzing the evolution of the hotel industry in South East Asia market. Destinations were selected based on their ranking among South East Asia market and also the availability of the data. Several key statistics were utilized to measure the relationship between destination and hotel industry. Destination is selected under the tourism topic because of its popularity in the tourism studies based on the extensive reviews. On top of that, destination image was selected as the key area in destination discipline due to the same reason.

Besides that, hotel industry became the representative for the hospitality industry based on the idea that travelers allocated approximately 40 percent from the total travelling budget for accommodation. In addition, the statistic for this hotel segment is readily available in the website as compared to other hospitality sub-industry. 


\section{RESULT AND DISCUSSION}

\section{A. The Progress of Destination Branding}

From the extensive literature search and statistics gathering, there are several notable findings from the reviews of the internet where the key market can be classified into several elements as shown in Table II.

TABLE II. KEY INFORMATION ON THE DESTINATION

\begin{tabular}{cccc}
\hline Country & Key Cities & Country Image & $\begin{array}{c}\text { Number of tourist } \\
\text { Arrivals (millions) }\end{array}$ \\
\hline Thailand & $\begin{array}{c}\text { Phuket, Bangkok \& } \\
\text { Chiang Mai }\end{array}$ & Beach and Nightlife & $32.6^{*}$ \\
Malaysia & $\begin{array}{c}\text { Penang, Malacca, Sabah \& } \\
\text { Kuala Lumpur }\end{array}$ & $\begin{array}{c}\text { Multicultural \& Street } \\
\text { Food }\end{array}$ & $26.8^{*}$ \\
Singapore & Singapore & Modern \& Street Food & $17.4^{*}$ \\
Indonesia & Bali and Jakarta & Island and Nightlife & $11.5^{* *}$ \\
Vietnam & Hanoi \& Ho Chi Minh & Historical Values & $10.0^{*}$ \\
Philippines & Palawan \& Boracay & Island & $6.0^{*}$ \\
\hline
\end{tabular}

Source: *(UNWTO, 2017; **Trading Economics, 2017)

From the above table, it is observed that the top three destinations in Asia are Thailand, Malaysia and Singapore. There are several country images are observed in the popular travel and tourism websites with no empirical evidences that assess the tourist evaluation of the destination image. From the review of the empirical findings on these three destinations, there were contradict findings on the best image to describe the destination. By comparing the inputs as retrieved in the popular websites against empirical findings, scholars only agreed with Thailand as the "beach" destination.

TABLE III. DESTINATION IMAGE FROM EMPIRICAL FINDINGS

\begin{tabular}{ccc}
\hline Thailand & Malaysia & Singapore \\
\hline Beach & Beautiful Scenery & Safety and Security \\
Affordable price & Beach & Business and convention \\
Shopping & Friendly people & Easy Access \\
Easy Access & Affordable price & Weather \\
Natural attractions & Shopping & Food \\
\hline
\end{tabular}

Source: (Hui,T.K., \& Wan,T.W.D., 200; Jogersen,L.G., 2004; Sharafuddin, M.A., 2015;

Som,A.P.M., Marzuki,A., Yousefi,M., \& Abu Khalifeh,A.N., 2012; Mohamad, D., \& Jamil,R.M., 2012; Rittichainuwat,B., 2010; Siri,R., Kennon,L., Josiam,B., \& Spears,D., 2012; Aung,H.M.,

\& Hichitake, Y., 2015; and Thiumsak,T., \& Ruangkanjanases,A., 2016.

In terms of official destination branding, it is observed that the Thailand, Malaysia, Singapore used general destination image as compared to Indonesia, Vietnam and the Philippines that used character to portray destination image (Table IV). 
TABLE IV. DESTINATION BRANDING

\begin{tabular}{ccc}
\hline Country & Key Segment & Destination Tagline \\
\hline Thailand & $\begin{array}{c}\text { China, Malaysia \& South } \\
\text { Korea }\end{array}$ & Amazing Thailand \\
Malaysia & $\begin{array}{c}\text { Singapore, Indonesia \& } \\
\text { China }\end{array}$ & Malaysia Truly Asia \\
Singapore & $\begin{array}{c}\text { Indonesia, China \& } \\
\text { Malaysia } \\
\text { Indonesia }\end{array}$ & Your Singapore \\
& $\begin{array}{c}\text { Singapore } \\
\text { Vietnam }\end{array}$ & China, South Korea and \\
& Japan & Wonderful Indonesia \\
Philippines & South Korea, United States \\
\& China & Timeless Charm \\
& It's more fun in the Philippines
\end{tabular}

Source. (Business Tip, 2017)

Destination branding is a process of creating a story about the city/place and aggressively communicates in the hope to form a prominent image. As referred to SEA destination tagline, the applicability of destination branding to tell the story about the destination branding is impossible by using a tagline. The most successful destination tagline is the one that can create spin-off for other merchandiser to get benefit from the tagline as observed in New York City "I love NY."

\section{B. The Progress of Hotel Branding}

In the hotel industry, several findings demonstrate the relationship between brand and satisfaction (Back, K.J., 2005; Tepeci,M., 1999), brand and trust (Chiang,C.F., \& Jang, S.S., 2007; Kayaman,R., \& Arasli, H., 2007), and brand and loyalty (back, K.J., 2005; Kim, H.B., \& Kim, W.G., 2005). To give better impact and to answer the "what-if" questions, using more than one outcome measurements have become a phenomenon in the hotel industry as observed in (Barsky,J., \& Nash, L., 2002; Choi,T.Y., \& Chu,R., 2001; Faullant,R., Matzler,K., \& Fuller,J., 2008; Kandampully, J., \& Suhartanto, D., 2000). With growing numbers of research in the brand areas, none of them suggesting how branding strategy as practiced in the hotel industry can be adopted in the destination branding. Even though destination branding taking into account a mass strategy that involved various stakeholders, synchronizing branding strategy to niche market will be beneficial for both industries.

For a start this research assessed the differences in performance for hotel industry with destination performance. Table 5 displayed the comparison between tourist arrivals and the occupancy rate of the countries in SEA. From the table, it shows that the top three average occupancy rate in SEA are Singapore $(80.9 \%)$, Thailand $(75.1 \%)$ and the Philippines $(67.5 \%)$. As compared to the market performance, Singapore (80.9\%), Hanoi (78.7\%) and Bangkok (77.4\%) are the top three cities in SEA with the highest occupancy rate.

Looking at the statistic of occupancy rate in SEA, destination branding as applied by the SEA country has no impact to the occupancy rate. The statistic shows that destination branding need a major revamped by incorporating brand as the identity of the major city. Hotel industry can communicate the city branding into their promotional package.

South East Asia is one of the popular market for Asian travelers, however looking at the current statistics, the destination can fulfill more demand from the major inbound tourist market in particular China, South Korea and Europeans. Major city in SEA must deploy and re-deploy strategies to become the top tourist destination in the world. Co-alignment of destination branding and hotel branding can give add-value for the destination especially to attract tourist from the luxury segment. 
TABLE V. DESTINATION BRANDING

\begin{tabular}{cccccc}
\hline Country & $\begin{array}{c}\text { Tourist Arrival } \\
\text { (millions) }\end{array}$ & Oct & Nov & Dec & $\begin{array}{c}\text { Average } \\
\text { Occupancy Rate }\end{array}$ \\
\hline Singapore & 17.4 & 78.5 & 79.6 & 75.6 & 80.9 \\
Thailand & 32.6 & 68.2 & 71.2 & 74.5 & 75.1 \\
Philippines & 6.0 & 65.4 & 71.8 & 68.2 & 67.5 \\
Vietnam & 10.0 & 66.5 & 72.8 & 69.3 & 67.3 \\
Malaysia & 26.8 & 61.9 & 67.1 & 67.7 & 63.9 \\
Indonesia & 11.5 & 63.2 & 62.6 & 61.1 & 60.0 \\
\hline
\end{tabular}

Source: (STR Hotel Review Report, 2017)

\section{V.CONCLUSION}

It is concluded that destination branding as observed in SEA market has no significant effect to the hotel industry. The practice of using general destination branding gave no added value for the hotel players in their promotional campaign. With more hotel developments in the city center, it will reduce the occupancy rate for the market and will give no benefit for the city branding.

\section{REFERENCES}

Agriculture. (n.d). In Oxford English dictionary online. Retrieved from http://www.oxforddictionaries.com/definition/english/agriculture.

Amin, M. (2010). How do manufacturing and service firms differ within the informal sectors? Enterprise Note (14). World Bank Group. Retrieved from http://www.enterprisesurveys.org/ /media/GIAWB/EnterpriseSurveys/

Aung, H. M., \& Hichitake, Y. Destination Image of Thailand and Singapore. APHEIT Journal, vol. 4, no. 2, July 2015.

Bertelsen, S. (2002). Bridging the gap - towards a comprehensive understanding of lean construction. Proceedings of the $10^{\text {th }}$ Annual Conference in the International Group for Lean Construction. Retrieved from http://www.bertelsen.org.

Back, K. J. (2005). The effects of image congruence on customers' brand loyalty in the upper middleclass hotel industry. Journal of Hospitality \& Tourism Research, 29(4), 448-467.

Barsky, J., \& Nash, L. (2002). Evoking emotion: affective keys to hotel loyalty. The Cornell Hotel and Restaurant Administration Quarterly, 43(1), 39-46.

Buhalis, D. Marketing the Competitive Destination of the Future. Available online: http://core.ac.uk/ download/pdf/101658.pdf (accessed on 27 Fabruary 2015).

Business Tips. Retrieved on December 14, 2017 from (https://businesstips.ph/list-of-tourism-slogansof-countries-around-the-world/

Chiang, C. F., \& Jang, S. S. (2007). The effects of perceived price and brand image on value and purchase intention: leisure travelers' attitudes toward online hotel booking. Journal of Hospitality \& Leisure Marketing, 15(3), 49-69.

Choi, T. Y., \& Chu, R. (2001). Determinants of hotel guests' satisfaction and repeat patronage in the Hong Kong hotel industry. International Journal of Hospitality Management, 20(3), 277-297.

Chon, K. S., \& Sparrowe, R.T. (2010). Welcome to hospitality: An introduction ( $3^{\text {rd }}$ Ed.). New York: Delmar.

Construction. (n.d). In Business Dictionary online. Retrieved from http://www.businessdictionary.com/definition/constructionindustry.html. 
Creswell, J. W. (2009). Research Design: qualitative, quantitative and mixed methods approaches (3rd Ed.). Thousand Oaks, CA: Sage.

Faullant, R., Matzler, K., \& Füller, J. (2008). The impact of satisfaction and image on loyalty: the case of Alpine ski resorts. Managing Service Quality: An International Journal, 18(2), 163178.

Hill, T., \& Westbrook, R. (1997). SWOT analysis: it's time for a product recall. Long range planning, 30(1), 46-52.

Hospitality. (n.d). In Oxford English dictionary online. Retrieved from http://www.oxforddictionaries.com/definition/english/hospitality

Howells, J. (2004). Innovation, consumption and services: encapsulation and the combinatorial role of services. Service Industries Journal, 24(1), 19-36.

Hui, T. K., \& Wan, T. W. D. (2003). Singapore's image as a tourist destination. International journal of tourism research, 5(4), 305-313.

IRTS (2008). International Recommendations for Tourism Products 2008. Department of Economic and Social Affairs, United Nations.

Jørgensen, L. G. (2004). An analysis of a destination's image and the language of tourism. UNIQUELY SINGAPORE, 9, 13.

Kandampully, J., \& Suhartanto, D. (2000). Customer loyalty in the hotel industry: the role of customer satisfaction and image. International Journal of Contemporary Hospitality Management, 12(6), 346-351.

Kastrone, I. (2009, November 3). 8 old colonial hotels you can still stay. Retrieved from http://www.bootsnall.com/articles/09-11/8-old-colonial-hotels-you-can-still-stay-in.html.

Kayaman, R., \& Arasli, H. (2007). Customer based brand equity: evidence from the hotel industry. Managing Service Quality: An International Journal, 17(1), 92-109.

Kim, H. B., \& Kim, W. G. (2005). The relationship between brand equity and firms' performance in luxury hotels and chain restaurants. Tourism Management, 26(4), 549-560.

Mackenzie, M., \& Chan, B. (2009). Introduction to hospitality. Hong Kong: Education Bureau.

Manufacturing. (n.d). In Business Dictionary online. Retrieved from http://www.businessdictionary.com/definition/manufacturing.html.

Margi, R. Travel: top 7 historic hotels in Indonesia. The Jakarta Post, February 4, 2015.

Mohamad, D., \& Jamil, R. M. (2012). A preference analysis model for selecting tourist destinations based on motivational factors: A case study in Kedah, Malaysia. Procedia-Social and Behavioral Sciences, 65, 20-25.

McCarthy, E. J. (1968). Basic marketing: A managerial approach. RD Irwin.

Powers, T \& Barrows, C. (2006). Introduction to the hospitality industry (6th Ed.). New Jersey: John Wiley \& Sons.

Rimmer, P. J., \& Dick, H. W. (2009). The city in Southeast Asia: Patterns, processes and policy. NUS Press.

Rittichainuwat, B. (2010). Image of Thailand as an International Convention and Exhibition Destination. Summit secretariat of the ICES 2010.

Service. (n.d). In Business Dictionary online. Retrieved from http://www.businessdictionary.com/definition/service-industry.html.

Sharafuddin, M. A. (2015). Types of Tourism in Thailand. E-review of Tourism Research, 12.

Sherry, J. E. (1993). The laws of innkeepers: for hotels, motels, restaurants, and clubs. New York: Cornell University Press.

Siri, R., Kennon, L., Josiam, B., \& Spears, D. (2012). Exploring Indian tourists' motivation and perception of Bangkok. Tourismos, 7(1).

Som, A. P. M., Marzuki, A., Yousefi, M., \& AbuKhalifeh, A. N. (2012). Factors influencing visitors' revisit behavioral intentions: a case study of Sabah, Malaysia. International Journal of marketing studies, 4(4), 39.

STR Hotel Review Report (2017) Asia Pacific Hotel Review (October - December 2017).

Tepeci, M. (1999). Increasing brand loyalty in the hospitality industry. International Journal of Contemporary Hospitality Management, 11(5), 223-230.

Thiumsak, T., \& Ruangkanjanases, A. (2016). Factors influencing international visitors to revisit Bangkok, Thailand. Journal of Economics, Business and Management, 4(3), 220-230. 
Trading Economics (2017) Indonesia Tourist Arrivals https://tradingeconomics.com/indonesia/touristarrivals

UNWTO (2017) Tourism Highlights. Retrieved on January 20, 2018 from https://www.eunwto.org/doi/pdf/10.18111/ 9789284419029.

Uratex Foam, "A Comforting Past: 3 historical hotels in the Philippines." http://www.uratex.com.ph/industrial-institutional/blog/a-comforting-past-3-historical-hotels-inthe-philippines. Available on June 10, 2015.

Vernon, R. (1966). The product life cycle. Quarterly Journal of Economics, 66, 121-140. 